\title{
Jenis Jenis Pohon Penyangga Sungai Bonti Kecamatan Bonti Kabupaten Sanggau
}

\author{
Muhammad Syukur \\ Fakultas Pertanian Universitas Kapuas Sintang \\ Email : msyukur1973@yahoo.co.id
}

\begin{abstract}
Abstrak: Penelitian ini bertujuan untuk mengetahui jenis jenis pohon penyangga pada sungai Bonti Kecamatan Bonti Kabupaten Sanggau. Penelitian ini dilaksanakan dengan menggunakan metode jalur/transek. Pada jalur/transek dibuatkan petak pengamatan secara kontinyu yang diletakan di kiri dan kanan jalur dengan ukuran $20 \times 20 \mathrm{~m}$. Jalur dibuat mengikuti bentuk sungai dengan panjang jalur pengamatan diperkirakan \pm adalah $1.500 \mathrm{~m}(1,5 \mathrm{~km})$, dengan demikian luas total areal pengamatan adalah $60.000 \mathrm{~m}^{2}$ atau sama dengan $6 \mathrm{Ha}$. Hasil penelitian diketahui bahwa terdapat 13 jenis pohon penyangga yang terdapat di kiri-kanan sungai Bonti dusun Sum Raya desa Bantai Kecamatan Bonti Kabupaten Sanggau, yaitu pohon Biau, Dayin, Diat, Hogah, Jito, Kawai, Kayu Aro, Kuang, Nunua, Puda, Sibau, Terindak dan Towo. Hanya dua jenis pohon penyangga yang dimanfaatkan kayunya oleh masyarakat yaitu jenis Terindak dan Diat (Durian), untuk dijadikan sebagai bahan baku membuat bangunan, sedangkan yang lain buahnya dimanfaatkan sebagai pakan satwa dan dikonsumsi langsung oleh masyarakat
\end{abstract}

Kata Kunci : Keanekaragaman Jenis dan Pohon Penyangga Sungai Bonti

\section{PENDAHULUAN}

Secara biologis, sungai merupakan salah suatu ekosistem penting yang di dalamnya berlangsung interaksi antar makhluk hidup dengan lingkungan fisik di sekitarnya. Peran penting ekosistem sungai dapat berupa tempat berlangsungnya siklus hidrologi yang menjadi kunci ketersediaan air di bumi, tempat berkembangbiaknya flora dan fauna di sungai, seperti ikan, kepiting, udang, serangga, dan tumbuh- tumbuhan yang membutuhkan kelembaban tinggi, sumber air untuk kehidupan dan budidaya manusia, seperti pertanian, perikanan, industri, transportasi dan rekreasi. Sungai berfungsi juga sebagai pereduksi polutan perairan dalam jumlah dan batas tertentu, serta menciptakan iklim mikro di sekitarnya. Peranan sungai tersebut dapat berlangsung dalam kondisi sungai yang stabil, yaitu kondisi sungai dengan bahanbahan pencemar ada dalam batas minimal yang bisa ditampung dan 
Jenis Jenis Pohon Penyangga Sungai Bonti Kecamatan Bonti Kabupaten Sanggau

masih bisa mendukung kehidupan di sungai secara normal. Selain itu, juga dipengaruhi oleh kondisi fisik sungai seperti kuantitas air, arus, kedalaman dan kecuraman sungai.

Setiap sungai memiliki zona penyangga, yang merupakan zona penghubung ekosistem daratan dan ekosistem perairan. Zona penyangga berfungsi untuk menjaga kelestarian fungsi sungai dengan cara menahan atau menangkap tanah (lumpur) yang tererosi serta unsur-unsur hara dan bahan kimia termasuk pestisida yang terbawa., dari lahan di bagian kiri dan kanan sungai agar tidak sampai masuk ke sungai. Posisi topografi yang berada di tepian sungai merupakan sumber utama air atau makanan bagi tumbuhan dan struktur yang ada merupakan tempat habitat berbagai macam flora dan fauna. Zona penyangga merupakan habitat berbagai jenis pohon dan fauna daratan. Zona penyangga juga penting untuk konservasi sumber daya air dan pelestarian habibat ikan. Kualitas air dan habitat ikan bergantung dari kelestarian jenis vegetasi (utamanya pohon) pada zona penyangga. Oleh karena itu perlindungan terhadap zona penyangga sangat diperlukan. Untuk melindungi dan memelihara fungsi ekologi dari zona penyangga diperlukan berbagai upaya dengan menyelaraskan antara upaya pemanfaatan dan tetap menjamin kelestarian keanekaragaman jenis vegetasi yang terdapat pada zona tersebut.

Hutan yang terdapat pada daerah penyangga sungai mempunyai peranan sangat penting baik secara ekologis sebagai penunjang kestabilan ekosistem karena berperan dalam siklus karbon, oksigen, nitrogen dan siklus air serta habitat berbagai macam flora dan fauna. Secara ekonomis hutan penyangga sungai adalah sumber utama pemenuhan kebutuhan bagi masyarakat setempat.

\section{METODE PENELITIAN}

Penelitian ini dilaksanakan dengan menggunakan metode jalur/transek. Pada jalur/transek dibuatkan petak pengamatan secara kontinyu yang diletakan di kiri dan kanan jalur dengan ukuran $20 \times 20 \mathrm{~m}$. Jalur dibuat mengikuti bentuk sungai dengan panjang jalur pengamatan 
Jenis Jenis Pohon Penyangga Sungai Bonti Kecamatan Bonti Kabupaten Sanggau

diperkirakan \pm adalah $1.500 \mathrm{~m}(1,5$ $\mathrm{km}$ ), dengan demikian luas total areal pengamatan adalah $60.000 \mathrm{~m}^{2}$ atau sama dengan $6 \mathrm{Ha}$.

Jalur pengamatan ditentukan berdasarkan hasil oberservasi lapangan, yaitu pada daerah yang dianggap paling representatif untuk mewakili kawasan hutan sungai Bonti Dusun Sum Raya Desa Bantai Kecamatan Bonti Kabupaten Sanggau. Jalur dibuat dikiri dan kanan tepi sungai Bonti. Selanjutnya pada jalur dibuat petak pengamatan secara kontinyu dengan ukuran $20 \mathrm{~m}$ x $20 \mathrm{~m}$. Petak pengamatan dibuat dan diletakkan secara berselangseling di sebelah kanan dan kiri sepanjang jalur pengamatan.

\section{HASIL DAN PEMBAHASAN}

Berdasarkan hasil pengamatan pada jalur yang dibuat dikiri dan kanan tepi sungai Bonti sepanjang 1.500 meter, maka ditemukan 13 jenis pohon penyangga. Adapun jenis-jenis pohon yang terdapat di kiri kanan tepi sengai Bonti dusun Sum Raya desa Bantai Kecamatan Bonti Kabupaten Sanggau, dapat dilihat pada tabel berikut ini.

Tabel 1.. Jenis Jenis Pohon Penyangga Sungai Bonti Pada Lokasi Penelitian

\begin{tabular}{llll}
\hline No & Nama Jenis (Lokal) & Nama Ilmiah & Famili \\
\hline 1 & Biau & Litsea $s p$ & Dipterocarpaceae \\
\hline 2 & Daying & Macaranga sp & Euphorbiaceae \\
\hline 3 & Diat (Durian) & Durio zibethinus & Malvaceae \\
\hline 4 & Hogah (Lengkeng Hutan) & Dimocarpus longan & Sapindaceae \\
\hline 5 & Jito (Pelaik) & Alstonia sp & Apocinaceae \\
\hline 6 & Kawai (Pekawai) & Durio kuteineinsis & Malvaceae \\
\hline 7 & Kayu Aro (Beringin) & Ficus $s p$ & Moraceae
\end{tabular}


Jenis Jenis Pohon Penyangga Sungai Bonti Kecamatan Bonti Kabupaten Sanggau

\begin{tabular}{llll}
\hline \hline No & Nama Jenis (Lokal) & Nama Ilmiah & Famili \\
\hline 8 & Kuang (Sengkuang) & Dracontomelon sp & Anacardiaceae \\
\hline 9 & Nunua (Beringin) & Ficus benjamina & Moraceae \\
\hline 10 & Puda (Cempedak Air) & Artocarpus sp & Moraceae \\
& & & Sapindaceae \\
\hline 11 & Sibau & Nephelium & Dipterocarpaceae \\
& & Shorea seminis & Moraceae \\
\hline 13 & Towo (Mentawak) & Artocarpus anisophyllus & \\
& & &
\end{tabular}

Sumber : Hasil Penelitian, 2020.

Berdasarkan hasil penelitian diketahui bahwa terdapat 13 jenis pohon penyangga, yang ditemukan di kiri-kanan sungai Bonti dusun Sum Raya. Jenis-jenis pohon yang ditemukan kayunya relatif kurang memiliki nilai ekonomis, kecuali jenis Terindak. Walaupun demikian, pohon yang terdapat pada lokasi penelitian umumnya adalah jenis penghasil buah-buahan, baik yang dapat dikonsumsi oleh manusia maupun sebagai pakan berbagai satwa. Hal ini mengindikasikan bahwa, sesungguhnya jenis-jenis pohon penyangga mempunyai peranan penting bagi kelangsungan/keberlanjutan hidup manusia dan satwa yang ada di sekitarnya, paling tidak sebagai 
Jenis Jenis Pohon Penyangga Sungai Bonti

Kecamatan Bonti Kabupaten Sanggau

lajunya erosi, menjaga suhu air sungai, sebagai tempat berkembangbiaknya biota air dan menjaga kejernihan serta kualitas air. Fungsi ini akan dapat lestari apabila jenis-jenis pohon penyangga masih tetap utuh, sebaliknya bilamana terdapat gangguan maka fungsi ekologisnya juga akan terganggu atau bahkan hilang sama sekali.

Masyarakat dusun Sum Raya memanfaat pohon yang terdapat di sungai Bonti untuk berbagai keperluan, utamanya untuk bahan bangunan. Jenis kayu yang digunakan adalah pohon Terindak dan Diat (Durian). Tanah yang terdapat di kiri-kanan sungai Bonti adalah tanah milik masyarakat perorangan, bukan milik negara atau masyarakat adat. Masyarakat pemilik tanah/lahan, memanfaatkan untuk berbagai aktivitas pertanian baik sebagai ladang maupun kebun rakyat. Tidak ada larangan bagi masyarakat untuk memanfaatkan lahannya, namun demikian sampai saat ini semua aktivitas tersebut masih pada ambang batas toleransi lingkungan, yang ditandai dengan masih jernihnya air sungai pada lokasi penelitian.
Daerah kiri-kanan sungai adalah wilayah yang sangat penting dalam menjaga keseimbangan ekosistem sungai, sekaligus sebagai wilayah yang sangat rentan gangguan. Adanya aktivitas masyarakat yang memanfaatkan lahan di kiri-kanan sungai Bonti, sesungguhnya merupakan ancaman terbesar bagi kelestarian fungsi kawasan. Sungai sebagai salah satu sumber air mempunyai fungsi yang sangat penting bagi kehidupan dan penghidupan masyarakat, perlu dijaga kelestariannya dan kelangsungan fungsinya dengan mengamankan daerah sekitarnya. Daerah penyangga sungai merupakan batas luar pengamanan sungai yang membatasi adanya pendirian bangunan di tepi sungai dan ditetapkan sebagai perlindungan sungai. Jaraknya bisa berbeda di tiap sungai, tergantung kedalaman sungai, keberadaan tanggul, posisi sungai, serta pengaruh air laut. Oleh sebab itu, maka dipandang perlu adanya campur tangan pemerintah untuk tetap memastikan fungsi kawasan penyangga sungai, sehingga terjamin kelestariannya. 


\section{PENUTUP}

\section{Kesimpulan}

Berdasarkan hasil penelitian dan pengamatan, maka dapat disimpulkan sebagai berikut;

1. Terdapat 13 jenis pohon penyangga yang terdapat di kirikanan sungai Bonti dusun Sum Raya desa Bantai Kecamatan Bonti Kabupaten Sanggau, yaitu pohon Biau, Dayin, Diat, Hogah, Jito, Kawai, Kayu Aro, Kuang, Nunua, Puda, Sibau, Terindak dan Towo.

2. Hanya dua jenis pohon penyangga yang dimanfaatkan kayunya oleh masyarakat yaitu jenis Terindak dan Diat (Durian), untuk dijadikan sebagai bahan baku membuat bangunan, sedangkan yang lain buahnya dimanfaatkan sebagai pakan satwa dan dikonsumsi langsung oleh masyarakat.

\section{Saran}

Mengingat begitu besarnya fungsi daerah penyangga sungai dan adanya aktivitas masyarakat pada daerah tersebut untuk pertanian baik ladang maupun kebun rakyat, maka perlu campur tangan pemerintah bersama mayarakat setempat untuk menjaga dan menjamin kelestarian fungsi kawasannya

\section{DAFTAR PUSTAKA}

Arsyad S. 2006. Konservasi Tanah dan Air. Bogor: IPB Press.

Binkley, D.,H. Burnham \& H.L.Allen. 1999. Water Quality Impacts of Forest Fertilization with Nirogen and Phosphorous. For. Ecol. Manage.

Loomis, J., P.Kent, L.Strange, K.Fausch \& A.Covich. 2000. Measuring The Total Economic Value of Restoring Ecosystem Services in an Impaired River Basin: Results from Contingent Valuation Survey. Ecological Economics

\section{Peraturan Menteri Pekerjaan Umum Nomor : 63/PRT/1993. tentang Garis Sempadan Sungai, Daerah Manfaat Sungai, Daerah Penguasaan Sungai Dan Bekas Sungai. Tanggal 27 Februari Tahun 1993.}

Petts, G.E. 1996. Sustaining the Ecological Integrity of Large Floodplain Rivers. Di dalam: Anderson, M.G., Walling, D.E., Bates, P.D. editor. Floodplain Processes. Chichester: John Wiley and Sons. 
Jenis Jenis Pohon Penyangga Sungai Bonti

Kecamatan Bonti Kabupaten Sanggau

Siahaan R dan Song N A, 2015. Jenis Jenis Vegetasi Riparian Sungai Ranoyapo, Minahasa Selatan. Jurnal LPPM Sains dan Teknologi. Unsrat Manado. Volume 1 Nomor 1 Oktober 2014.

Soerianegara I dan A. Indrawan. 2005. Ekosistem Hutan Indonesia. Bogor : Laboratorium Ekologi Hutan, Fakultas Kehutanan IPB.
Tjitrosoepomo G. 2003. Taksonomi Tumbuhan. Gadjah Mada University Press. Yogyakarta.

Undang Undang Nomor 5 Tahun 1990. Tentang Konservasi Sumber Daya Alam Hayati dan Ekosistemnya. Tanggal 10 Agustus 1990. Kepala Biro Hukum dan Perundan Undangan RI. 